\title{
Impact of neoadjuvant chemoradiotherapy on post-operative clinically significant pancreatic fistula - A systemic review and updated meta-analysis.
}

Dr.Bhavin Vasavada, MS,

Consultant hepatopancreaticobiliary and liver transplant surgeon,

Department of hepatobiliary and liver transplant surgery,

Shalby Hospitals,

Ahmedabad.

India.

Email: drbhavin.liversurgeon@gmail.com.

Dr.Hardik Patel. MS,

Consultant hepatopancreaticobiliary and liver transplant surgeon,

Department of hepatobiliary and liver transplant surgery,

Shalby Hospitals,

Ahmedabad.

India.

Keywords: Meta-analysis; neoadjuvant chemoradiotherapy; pancreatic surgery; pancreaticoduodenectomy; pancreatic fistula.

Conflict of interests: none

Funding disclosure: none. 


\begin{abstract}
:
Background:

Pancreatic fistula is one of the main complications after pancreatic surgery and the leading cause of morbidity and mortality after pancreatic surgery. There are many pieces of evidence emerging out from retrospective studies and metanalysis that neoadjuvant chemoradiation decreases rates of clinically significant postoperative pancreatic fistula.
\end{abstract}

\title{
Aims and objectives:
}

The primary aim of our analysis was to do a systemic review and updated meta-analysis of literature published in the last 10 years and look for the association of neoadjuvant chemoradiation and risk of subsequent clinically significant pancreatic fistula.

\section{Methods:}

EMBASE, MEDLINE, and the Cochrane Database were searched for

Studies comparing outcomes in patients receiving neoadjuvant chemoradiotherapy first

with those patients who received surgery first in case of pancreatic cancer. A systemic review and Metanalysis were done according to MOOSE and PRISMA guidelines. Heterogeneity was measured using Q tests and I2, and $\mathrm{p}<0.10$ was determined as significant. The Odds ratios (OR) and Risk Ratios (RR) were calculated for dichotomous data as per the requirement, and weighted mean differences (WMD) were used for continuous variables. Nonrandomized trials were accessed for bias using the New Castle Ottawa scale. Publication bias was studied using funnel plots. The meta-analysis was conducted using Open Review Manager 5.4.

\section{Results:}

Twenty-six studies including 17021 patients finally included in the analysis. 339 patients out of a total of 3386 developed clinically significant pancreatic fistula in the neoadjuvant first group. 2342 patients out of 13335 patients developed clinically significant pancreatic fistula 
in the surgery first group. Neoadjuvant treatment significantly reduced the risk of subsequent clinically significant pancreatic fistula. $(p=<0.0001)$. The number of patients with soft pancreas was significantly higher in the surgery first group. $(\mathrm{p}<0.0001)$. Pancreatic duct diameter mentioned in only two studies but there was no significant difference between both groups. [p=1].Blood loss was significantly more in the surgery first group. $[\mathrm{p}<0.0001]$. There was no difference in pancreaticoduodenectomy or distal pancreatectomy performed between both groups. $(\mathrm{p}=0.82)$. There was no difference in the number of borderline resectable pancreatic tumors between both groups. $(\mathrm{p}=0.34)$. There was no difference in overall grade 3/grade 4 complications rate between both groups. $(p=0.39)$.

\section{Conclusion:}

Neoadjuvant treatments may be responsible for the lower rates of clinically significant pancreatic fistula after subsequent surgery. 


\section{Background:}

Pancreatic fistula is one of the main complications after pancreatic surgery and the leading cause of morbidity and mortality after pancreatic surgery. In spite of all the scientific progress pancreatic surgery is still associated with very high complication rates. $[1,2,3,4]$.Pancreaticoduodenectomy is generally performed for pancreatic ductal adenocarcinoma in the head region and distal pancreatectomy for the body and tail region. R0 resection is necessary to increase the chances of long-term survival. When a tumor invades the superior mesenteric vein or superior mesenteric artery it is sometimes difficult to achieve R0 resection, which can hamper chances of long-term survival. These tumors are defined as borderline resectable tumors. [5,6,7] Consensus definition of borderline resectable pancreatic cancer includes anatomical considerations(contact with $<180$ degrees of the superior mesenteric artery and/or celiac artery, short segment contact with the common hepatic artery, and contact or occlusion with the superior mesenteric vein $\square$ portal vein confluence with adequate vein proximal and distal for reconstruction, high $\square$ risk biologic features, and patient performance status. [8,9]. Some studies have shown that neoadjuvant chemoradiation improves $\mathrm{R} 0$ resection rates in borderline resectable pancreatic tumors. the current National Comprehensive Cancer Network guidelines recommend neoadjuvant treatment for borderline resectable pancreatic tumors. [10,11]

Now there are many shreds of evidence emerging out from retrospective studies and metanalysis that neoadjuvant chemoradiation decreases rates of clinically significant postoperative pancreatic fistula. $[13,14,15]$

\section{AIMS AND OBJECTIVES:}

The primary aim of our analysis was to do a systemic review and updated meta-analysis of 
literature published in the last 10 years and look for the association of neoadjuvant chemoradiation and risk of subsequent clinically significant pancreatic fistula. We also looked for other components of fistula risk score between the neoadjuvant chemoradiotherapy group and the surgery first group.[16]

\section{Material and Methods:}

EMBASE, MEDLINE, and the Cochrane Database were searched for Studies comparing outcomes in patients receiving neoadjuvant chemoradiotherapy first with those patients who received surgery first in case of pancreatic cancer. We used keywords like "neoadjuvant chemoradiotherapy" "pancreas cancer" "Surgery first" "borderline resectable pancreas cancer". Only English language articles selected. Two independent authors extracted the data (B.V and H.P). Discussions and mutual understanding resolved any disagreements. A systemic review and Metanalysis were done according to MOOSE and PRISMA guidelines. $[17,18]$

\section{Statistical analysis}

The meta-analysis was conducted using Open Review Manager 5.4. Heterogeneity was measured using Q tests and I2, and $\mathrm{p}<0.10$ was determined as significant [19]. If there was no or low heterogeneity (I $<25 \%$ ), then the fixed-effects model was used. Otherwise, the random-effects model was used. The Odds ratios $(\mathrm{OR})$ and Risk Ratios $(\mathrm{RR})$ were calculated for dichotomous data as per the requirement, and weighted mean differences (WMD) were used for continuous variables. Both differences were presented with $95 \%$ CI. For continuous variables, if data were presented with medians and ranges, then we calculated the means and Standard deviations according to Hozo et al. [20]. If the study presented the median and interquartile range, the median was treated as the mean, and the interquartile ranges were calculated using 1.35 SDs, as described in the Cochrane handbook. 


\section{Assessment of Bias:}

Nonrandomized trials were accessed using the New Castle Ottawa scale [21] and randomized trials were accessed using the Cochrane handbook. [22]. Publication bias was studied using funnel plots.[Supplement Figure 1]. all relevant data were available from the original publications. We did not impute any missing outcome data. We presented the overall quality of the evidence for each outcome according to the GRADE approach, which takes into account issues not only related to internal validity (risk of bias, inconsistency, imprecision, publication bias) but also to external validity such as directness of results. [24]. We created a 'Summary of findings' table based on the methods described in the Cochrane Handbook for Systematic Reviews of Intervention. [25]

\section{Definitions:}

We defined clinically significant pancreatic fistula as per the ISGPS definition. [24] and we included any neoadjuvant therapy in the neoadjuvant therapy group.

\section{Inclusion criteria of studies:}

- Full-text articles

- Articles containing both neoadjuvant chemoradiotherapy group and surgery first group

- Studied published in the last 10 years.

- English language articles

- Studies which included pancreatic fistula analysis 
- Study involving pancreas ductal adenocarcinoma only.

\section{Exclusion criteria:}

- Articles where full texts could not be obtained

- Duplicate studies

- Studies that used duplicate data

Articles without the English language

\section{Results:}

\section{Study Selection:}

The study selection process is described in Figure: 1 as per PRISMA guidelines. Twenty-six studies including 17021 patients finally included in the analysis. [26-51]. Study characteristics are described in Table 1.3386 patients were in the neoadjuvant chemoradiation group and 13335 patients were in the surgery first group. The risk of bias summary is described in Figure 2.

\section{Comparisons of pancreatic fistulas between neoadjuvant first and surgery first:}

339 patients out of a total of 3386 developed clinically significant pancreatic fistula in the neoadjuvant first group. 2342 patients out of 13335 patients developed clinically significant pancreatic fistula in the surgery first group. Neoadjuvant treatment significantly reduced the risk of subsequent clinically significant pancreatic fistula. 
$(\mathrm{p}=<0.0001$, Risk ratio $0.66,95 \%$ confidence interval of risk ratio 0.55-0.81). [Figure 3]

\section{Components of Intraoperative fistula risk score:}

We also compared other components of fistula risk scores like gland textures (soft or not), blood loss, or duct diameter. The number of patients with soft pancreas was significantly higher in the surgery first group. ( $p<0.0001$ ). Pancreatic duct diameter mentioned in only two studies but there was no significant difference between both groups. [p=1].Blood loss was significantly more in the surgery first group.[Mean difference $125.69 \mathrm{ml}, 95 \%$ confidence interval 69.52-181.86 ml, p <0.0001] [Figure 4]. We included studies with pancreatic ductal adenocarcinomas only, so histology was similar in both the groups.

Type of surgeries, borderline resectable pancreatic tumor, and overall grade 3/grade 4 complications:

There was no difference in pancreaticoduodenectomy or distal pancreatectomy performed between both groups. $(\mathrm{p}=0.82)$. There was no difference in the number of borderline resectable pancreatic tumors between both groups. $(\mathrm{p}=0.34)$. There was no difference in overall grade 3/grade 4 complications rate between both groups. $(\mathrm{p}=$ 0.39). [Figure 5].

\section{DISCUSSION:}

Neoadjuvant chemoradiotherapy is increasingly being used in pancreatic cancer to achieve increase R0 rates, NCCN guidelines also recommend neoadjuvant chemoradiotherapy as a part of the treatment protocol. [10,11]. Recently published meta-analysis has shown increased overall survival in such patients. [12] however, 
there was some concern about increased complication rates following neoadjuvant chemoradiotherapy protocol. The PREOPANC randomized control trial [49] showed that neoadjuvant protocol did not increase complication rates.

The PREOPANC trial and many other studies showed $[49,50,51]$ that neoadjuvant chemoradiotherapy decreased postoperative pancreatic fistula rates also. These findings have been confirmed with systemic reviews and meta-analysis also.[52]. Increased fibrosis post neoadjuvant chemotherapy has been suggested as one of the factors responsible for decreasing postoperative fistula rates in the neoadjuvant protocol.[53,54].In addition, it is suggested that delayed surgery in the neoadjuvant group can increase inflammatory changes due to prolong pancreatic ductal obstruction. [49].

Our aim was to analyze the effect of neoadjuvant chemoradiation on subsequent postoperative fistula rates by updated meta-analysis including all the recent publications in the last 10 years. We also analyzed other components of intraoperative fistula risk score like gland texture, blood loss, pancreatic duct size. We included studies with pancreatic ductal adenocarcinoma only, so histology was similar in the neoadjuvant first and surgery first group.

Pancreatic fistula rates were significantly lower in the neoadjuvant group. [Risk Ratio 0.66 (95 \% C.I. 0.55-0.81). However, there were significantly fewer numbers of the soft pancreas and more mean blood loss in the neoadjuvant group. It shows that inflammatory changes post neoadjuvant therapy may help in decreasing intraoperative fistula risk score and may be responsible for decrease post-operative fistula risk score. Only two studies mentioned mean pancreatic diameter in their analysis, there was no 
significant difference in pancreatic duct diameter in both groups. PREOPANC trial [49] failed to show any difference in inflammatory changes between neoadjuvant and surgery first groups, but as discussed above our meta-analysis clearly showed that inflammatory changes were more prominent in the neoadjuvant group.

We also analyzed other confounding factors like the number of borderline resectable tumors and complication rates. Which showed no significant difference between two groups, further confirming the impact of neoadjuvant chemoradiotherapy on subsequent pancreatic fistula.

Our meta-analysis included all the recent publications regarding the impact of neoadjuvant treatment on subsequent postoperative pancreatic fistula and to our knowledge, this is the first meta-analysis that also included all the components of the fistula risk score. As, it is difficult to design randomized control trials in oncology keeping parameters like post-operative pancreatic fistula as the primary outcome, so such meta-analysis helps in obtaining more reliable shreds of evidence about the impact of neoadjuvant treatment on post-operative pancreatic fistula.

The majority of patients in the meta-analysis were having borderline resectable pancreatic cancer. Some centers are researching the impact of neoadjuvant chemotherapy on resectable pancreatic cancers.[55] The beneficial role of neoadjuvant treatment on subsequent clinically significant pancreatic fistula will make the case of using neoadjuvant chemoradiotherapy in this subgroup stronger.

There are certain limitations of this review heterogeneity was moderate to high in our analysis, though we used a random-effect model. There was also a single randomized control trial was available to include in this meta-analysis. As shown in figure 2, the 
risk of bias was high in some studies. As shown via funnel plots in supplement figure 1, we cannot entirely rule out the risk of publication bias also.

In, conclusion neoadjuvant treatments may be responsible for a lower rate of clinically significant pancreatic fistula after subsequent surgery, most likely due to its inflammatory response.

\section{References:}

1. Bartoli FG, Arnone GB, Ravera G, Bachi V. Pancreatic fistula and relative mortality in malignant disease after pancreaticoduodenectomy. Review and statistical meta $\square$ analysis regarding 15 years of literature. Anticancer Res. 1991;11(5):1831 $\square 1848$.

2. Vallance AE, Young AL, Macutkiewicz C, et al. Calculating the risk of a pancreatic fistula after a pancreaticoduodenectomy: a systematic review. HPB (Oxford). 2015;17(11):1040 $\square 1048$.

3. Addeo P, Delpero JR, Paye F, et al. Pancreatic fistula after a pancreaticoduodenectomy for ductal adenocarcinoma and its association with morbidity: a multicentre study of the French Surgical Association. HPB (Oxford). 2014;16(1):46ø55.

4. Ahmad SA, Edwards MJ, Sutton JM, et al. Factors influencing readmission after pancreaticoduodenectomy: a multi $\square$ institutional study of 1302 patients. Ann Surg. 2012;256(3):529 $\square 537$.

5. Neoptolemos JP, Stocken DD, Dunn JA, et al. Influence ofresection margins on survival for patients with pancreatic cancertreated by adjuvant chemoradiation and/or chemotherapy in the

ESPAC $\square 1$ randomized controlled trial. Ann Surg. 2001;234(6):758 $\square 768$. 
6. Richter A, Niedergethmann M, Sturm W, Lorenz D, Post S, Trede M. Long $\square$ term results of partial pancreaticoduodenectomy for ductal adenocarcinoma of the pancreatic head:

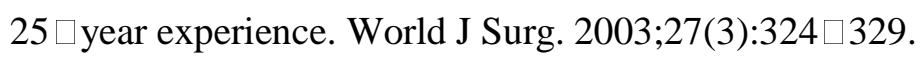

6. Kuhlmann KFD, de Castro SMM, Wesseling JG, et al. Surgical treatment of pancreatic adenocarcinoma; actual survival and prognostic factors in 343 patients. Eur J Cancer. 2004;40(4):549 $\square 558$.

7. Ryan DP, Hong TS, Bardeesy N. Pancreatic adenocarcinoma. N Engl J Med. 2014;371(11):1039 $\square 1049$.

8. Isaji S, Mizuno S, Windsor JA, et al. International consensus on definition and criteria of borderline resectable pancreatic ductal adenocarcinoma 2017. Pancreatology. 2018;18(1):2 $\square 11$.

9. Katz MHG, Pisters PWT, Evans DB, et al. Borderline resectable pancreatic cancer: the importance of this emerging stage of disease. J Am Coll Surg. 2008;206(5):833 $\square 848$.

J Am Coll Surg. 2008;206(5):833 $\square 848$.

10. Gillen S, Schuster $\mathrm{T}$, Meyer Zum Bu $\square$ schenfelde $\mathrm{C}$, Friess $\mathrm{H}$, Kleeff J.Preoperative/neoadjuvant therapy in pancreatic cancer: a systematic review and meta $\square$ analysis of response and resection percentages. PLOS Med. 2010;7(4):15.

11. Network NCC. Pancreatic Adenocarcinoma (Version 1.2018). https://www.nccn.org/professionals/physician_gls/PDF/pancreatic.pdf.

12. Versteijne E, Vogel JA, Besselink MG, et al. Meta-analysis comparing upfront surgery with neoadjuvant treatment in patients with resectable or borderline resectable pancreatic cancer. Br J Surg. 2018;105:946-958.

13. Czosnyka NM, Borgert AJ, Smith TJ. Pancreatic adenocarcinoma: effects of neoadjuvant therapy on post-pancreatectomy outcomes - an American College of Surgeons National 
Surgical Quality Improvement Program targeted variable review. HPB (Oxford). 2017 Oct;19(10):927-932.

14. Dahdaleh FS, Naffouje SA, Hanna MH, Salti GI. Impact of Neoadjuvant Systemic Therapy on Pancreatic Fistula Rates Following Pancreatectomy: a Population-Based Propensity-Matched Analysis. J Gastrointest Surg. 2020 Apr 6.

15. Cools KS, Sanoff HK, Kim HJ, Yeh JJ, Stitzenberg KB. Impact of neoadjuvant therapy on postoperative outcomes after pancreaticoduodenectomy. J Surg Oncol. 2018 Sep;118(3):455-462.

16. Callery MP, Pratt WB, Kent TS, Chaikof EL, Vollmer CM Jr. A prospectively validated clinical risk score accurately predicts pancreatic fistula after pancreatoduodenectomy. J Am Coll Surg. 2013 Jan;216(1):1-14.

17. Stroup DF, Berlin JA, Morton SC, et al. Meta-analysis of observational studies in epidemiology: a proposal for reporting. Meta-analysis Of Observational Studies in Epidemiology (MOOSE) group. JAMA. 2000 Apr 19;2008-12.

18. Liberati A, Altman DG, Tetzlaff J et al. The PRISMA statement for reporting systematic reviews and meta-analyses of studies that evaluate health care interventions: explanation and elaboration. J Clin Epidemiol. 2009 Oct; e1-34.

19. Hu Y, Huang C, Sun Y, Su X, Cao H, Hu J et al. Morbidity and Mortality of Laparoscopic Versus Open D2 Distal Gastrectomy for Advanced Gastric Cancer: A Randomized Controlled Trial. J Clin Oncol. 2016 Apr 20;34(12):1350-7.

20. Hozo SP, Djulbegovic B, Hozo I (2005) Estimating the mean and variance from the median, range, and the size of a sample. BMC Med Res Methodol 5:13.

21. HigginsJP, AltmanDG, GøtzschePC,et al. TheCochraneCollaboration'stool for assessing risk of bias in randomized trials. BMJ. 2011;343: d5928. 
22. Wells G, Shea B, O’Connell D, et al. The Newcastle-Ottawa Scale (NOS) for assessing the quality of nonrandomised studies in meta-analyses. September 1, 2016.

23. Langendam MW, Akl EA, Dahm P, Glasziou P, Guyatt G, Schünemann HJ. Assessing and presenting summaries of evidence in Cochrane Reviews. Syst Rev. 2013;2:81. Published 2013 Sep 23. doi:10.1186/2046-4053-2-81.

24. Schünemann HJ, Oxman AD, Higgins JPT, Vist GE, Glasziou P, Guyatt GH. Chapter 11: Presenting results and 'Summary of findings' tables. In: Higgins JPT, Green S (editors), Cochrane Handbook for Systematic Reviews of Interventions Version 5.1.0 (updated March 2011). The Cochrane Collaboration, 2011. Available from handbook.cochrane.org.

25. Bassi C, Marchegiani G, Dervenis C, et al. The 2016 update of the International Study Group (ISGPS) definition and grading of postoperative pancreatic fistula: 11 Years After. Surgery. 2017;161(3):584-591.

26. Araujo RLC, Silva RO, de Pádua Souza C, et al. Does neoadjuvant therapy for pancreatic head adenocarcinoma increase postoperative morbidity? A systematic review of the literature with meta-analysis. J Surg Oncol. 2020;121(5):881-892.

27. Barenboim A, Lahat G, Geva R, et al. Neoadjuvant FOLFIRINOX for locally advanced and borderline resectable pancreatic cancer: An intention to treat analysis. Eur J Surg Oncol. 2018;44(10):1619-1623.

28. Cloyd JM, Wang H, Overman M, et al. Influence of Preoperative Therapy on Short- and Long-Term Outcomes of Patients with Adenocarcinoma of the Ampulla of Vater. Ann Surg Oncol. 2017;24(7):2031-2039. 
29. Cooper AB, Parmar AD, Riall TS, et al. Does the use of neoadjuvant therapy for pancreatic adenocarcinoma increase postoperative morbidity and mortality rates?. $J$ Gastrointest Surg. 2015;19(1):80-87.

30. Denost Q, Laurent C, Adam JP, et al. Pancreaticoduodenectomy following chemoradiotherapy for locally advanced adenocarcinoma of the pancreatic head. $H P B$ (Oxford). 2013;15(9):716-723.

31. Ellis RJ, Brock Hewitt D, Liu JB, et al. Preoperative risk evaluation for pancreatic fistula after pancreaticoduodenectomy. J Surg Oncol. 2019;119(8):1128-1134.

32. Epelboym I, DiNorcia J, Winner M, et al. Neoadjuvant therapy and vascular resection during pancreaticoduodenectomy: shifting the survival curve for patients with locally advanced pancreatic cancer. World J Surg. 2014;38(5):1184-1195.

33. Denbo JW, Bruno ML, Cloyd JM, et al. Preoperative Chemoradiation for Pancreatic Adenocarcinoma Does Not Increase 90-Day Postoperative Morbidity or Mortality. $J$ Gastrointest Surg. 2016;20(12):1975-1985.

34. Jiang H, Du C, Cai M, et al. An evaluation of neoadjuvant chemoradiotherapy for patients with resectable pancreatic ductal adenocarcinoma. HPB Surg. 2013;2013:298726.

35. Lee JH, Kang CM, Bang SM, et al. The Role of Neoadjuvant Chemoradiation Therapy in Patients With Borderline Resectable Pancreatic Cancer With Isolated Venous Vascular Involvement. Medicine (Baltimore). 2015;94(31):e1233.

36. Marchegiani G, Andrianello S, Nessi C, et al. Neoadjuvant Therapy Versus Upfront Resection for Pancreatic Cancer: The Actual Spectrum and Clinical Burden of Postoperative Complications. Ann Surg Oncol. 2018;25(3):626-637.

37. Mellon EA, Strom TJ, Hoffe SE, et al. Favourable perioperative outcomes after resection of borderline resectable pancreatic cancer treated with neoadjuvant stereotactic radiation and 
chemotherapy compared with upfront pancreatectomy for resectable cancer. J Gastrointest Oncol. 2016;7(4):547-555.

38. Rykina-Tameeva N, Nahm CB, Mehta S, Gill AJ, Samra JS, Mittal A. Neoadjuvant therapy for pancreatic cancer changes the composition of the pancreatic parenchyma. $H P B$ (Oxford). 2020;22(11):1631-1636.

39. Tabchouri N, Bouquot M, Hermand H, et al. A Novel Pancreatic Fistula Risk Score Including Preoperative Radiation Therapy in Pancreatic Cancer Patients [published online ahead of print, 2020 Apr 20]. J Gastrointest Surg.

40. Paye F, Micelli Lupinacci R, Bachellier P, Boher JM, Delpero JR; French Surgical Association (AFC). Distal pancreatectomy for pancreatic carcinoma in the era of multimodal treatment. Br J Surg. 2015;102(3):229-236.

41. Takahashi H, Ogawa H, Ohigashi H, et al. Preoperative chemoradiation reduces the risk of pancreatic fistula after distal pancreatectomy for pancreatic adenocarcinoma. Surgery. 2011;150(3):547-556.

42. Tashiro M, Yamada S, Sonohara F, Takami H, Suenaga M, Hayashi M, Niwa Y, Tanaka C, Kobayashi D, Nakayama G, Koike M, Fujiwara M, Fujii T, Kodera Y. Clinical Impact of Neoadjuvant Therapy on Nutritional Status in Pancreatic Cancer. Ann Surg Oncol. 2018 Oct;25(11):3365-3371.

43. Timmermann L, Rosumeck N, Klein F, et al. Neoadjuvant Chemotherapy Enhances Local Postoperative Histopathological Tumour Stage in Borderline Resectable Pancreatic Cancer A Matched-Pair Analysis. Anticancer Res. 2019;39(10):5781-5787.

44. Uchida Y, Masui T, Nagai K, et al. Postoperative pancreatic fistulas decrease the survival of pancreatic cancer patients treated with surgery after neoadjuvant chemoradiotherapy: A retrospective analysis [published online ahead of print, 2020 Oct 24]. Surg Oncol. 2020;35:527-532. doi:10.1016/j.suronc.2020.10.010 
45. Yoshitomi H, Sakai N, Kagawa S, et al. Feasibility and safety of distal pancreatectomy with en bloc celiac axis resection (DP-CAR) combined with neoadjuvant therapy for borderline resectable and unresectable pancreatic body/tail cancer. Langenbecks Arch Surg. 2019;404(4):451-458.

46. Yoshiya S, Fukuzawa K, Inokuchi S, et al. Efficacy of Neoadjuvant Chemotherapy in Distal Pancreatectomy with En Bloc Celiac Axis Resection (DP-CAR) for Locally Advanced Pancreatic Cancer. J Gastrointest Surg. 2020;24(7):1605-1611.

47. Pecorelli N, Braga M, Doglioni C, et al. Preoperative chemotherapy does not adversely affect pancreatic structure and short-term outcome after pancreatectomy. J Gastrointest Surg. 2013;17(3):488-493.

48. Pecorelli N, Pagnanelli M, Cinelli L, et al. Postoperative Outcomes and Functional Recovery After Preoperative Combination Chemotherapy for Pancreatic Cancer: A Propensity Score-Matched Study. Front Oncol. 2019;9:1299. Published 2019 Nov 26.

49. van Dongen JC, Suker M, Versteijne E, et al. Surgical Complications in a Multicentre Randomized Trial Comparing Preoperative Chemoradiotherapy and Immediate Surgery in Patients With Resectable and Borderline Resectable Pancreatic Cancer (PREOPANC Trial) [published online ahead of print, 2020 Nov 12]. Ann Surg. 2020;10.1097/SLA.0000000000004313.

50. Sho M, Akahori T, Tanaka T, et al. Pathological and clinical impact of neoadjuvant chemoradiotherapy using full-dose gemcitabine and concurrent radiation for resectable pancreatic cancer. J Hepatobiliary Pancreat Sci. 2013;20(2):197-205.

51. Lof S, Korrel M, van Hilst J, et al. Impact of Neoadjuvant Therapy in Resected Pancreatic Ductal Adenocarcinoma of the Pancreatic Body or Tail on Surgical and Oncological Outcome: A Propensity-Score Matched Multicentre Study. Ann Surg Oncol. 2020;27(6):1986-1996. 
52. Kamarajah SK, Bundred JR, Boyle C, Oo J, Pandanaboyana S, Loveday B. Impact of neoadjuvant therapy on post-operative pancreatic fistula: a systematic review and metaanalysis. ANZ J Surg. 2020 Nov;90(11):2201-2210.

53. Matsuda Y, Inoue Y, Hiratsuka M, et al. Encapsulating fibrosis following neoadjuvant chemotherapy is correlated with outcomes in patients with pancreatic cancer. PLoS One. 2019;14:e222155.

54. Sasson AR, Wetherington RW, Hoffman JP, et al. Neoadjuvant chemoradiotherapy for adenocarcinoma of the pancreas: analysis of histopathology and outcome. Int $\mathbf{J}$ Gastrointest Cancer. 2003;34:121-128.

55. Thanikachalam K, Damarla V, Seixas T, et al. Neoadjuvant Phase II Trial of Chemoradiotherapy in Patients with Resectable and Borderline Resectable Pancreatic Cancer. Am J Clin Oncol. 2020;43(6):435-441. 
medRxiv preprint doi: https://doi.org/10.1101/2020.12.14.20248164; this version posted December 16, 2020. The copyright holder for this preprint (which was not certified by peer review) is the author/funder, who has granted medRxiv a license to display the preprint in perpetuity.

It is made available under a CC-BY-NC-ND 4.0 International license .

TABLE: 1 STUDY CHARACTERISTICS:

\begin{tabular}{|l|l|l|l|l|l|}
\hline STYDY ID & YEAR & TIME & TYPE OF & TOTAL & TOTAL \\
& & PERIOD & STUDY & PATIENT IN & PATIENT \\
& & & & NEOADJUVANT & IN \\
& & & ARM & SURGERY & FIRST \\
\hline Araujo et al. & 2013 & $2001-2011$ & Retrospective & 29 & ARM \\
\hline Barenboim et & 2008 & $2014-2017$ & Retrospective & 23 & 29 \\
\hline al. & & & cohort & & 47 \\
\hline Cloyd et al. & 2017 & $1999-2014$ & Retrospective & & \\
\hline
\end{tabular}


medRxiv preprint doi: https://doi.org/10.1101/2020.12.14.20248164; this version posted December 16, 2020. The copyright holder for this preprint (which was not certified by peer review) is the author/funder, who has granted medRxiv a license to display the preprint in perpetuity.

It is made available under a CC-BY-NC-ND 4.0 International license .

\begin{tabular}{|c|c|c|c|c|c|}
\hline & & & cohort & 43 & \\
\hline Cooper et al. & 2015 & 2011-2012 & $\begin{array}{l}\text { Retrospective } \\
\text { cohort }\end{array}$ & 199 & 1363 \\
\hline Denost et al. & 2013 & 2004-2009 & $\begin{array}{l}\text { Retrospective } \\
\text { cohort }\end{array}$ & 39 & 72 \\
\hline Ellis et al. & 2019 & 2014-2017 & $\begin{array}{l}\text { Retrospective } \\
\text { cohort }\end{array}$ & 1864 & 8158 \\
\hline $\begin{array}{l}\text { Epemboym et } \\
\text { al. }\end{array}$ & 2013 & 1992-2011 & $\begin{array}{l}\text { Retrospective } \\
\text { cohort }\end{array}$ & 143 & 363 \\
\hline Jason et al & 2016 & $2011-2015$ & $\begin{array}{l}\text { Prospective } \\
\text { cohort }\end{array}$ & 137 & 72 \\
\hline Jiang et al. & 2013 & $2004-2010$ & $\begin{array}{l}\text { Retrospective } \\
\text { cohort }\end{array}$ & 112 & 120 \\
\hline Lee et al. & 2015 & $2000-2013$ & $\begin{array}{l}\text { Retrospective } \\
\text { cohort }\end{array}$ & 30 & 28 \\
\hline Lof et al. & 2019 & $2007-2015$ & $\begin{array}{l}\text { Retrospective } \\
\text { cohort }\end{array}$ & 136 & 1100 \\
\hline $\begin{array}{l}\text { Marchegiani } \\
\text { et al. }\end{array}$ & 2017 & 2014-2016 & $\begin{array}{l}\text { Retrospective } \\
\text { cohort }\end{array}$ & 99 & 206 \\
\hline Mellon et al. & 2016 & $2000-2012$ & $\begin{array}{l}\text { Retrospective } \\
\text { cohort }\end{array}$ & 61 & 241 \\
\hline Nadya et al. & 2020 & 2011-2017 & $\begin{array}{l}\text { Prospective } \\
\text { cohort }\end{array}$ & 76 & 58 \\
\hline Nicolas et al. & 2020 & 2012-2017 & Retrospective & 164 & 284 \\
\hline
\end{tabular}




\begin{tabular}{|c|c|c|c|c|c|}
\hline & & & cohort & & \\
\hline Paye et al. & 2014 & 2004-2009 & $\begin{array}{l}\text { Retrospective } \\
\text { cohort }\end{array}$ & 39 & 248 \\
\hline Pecorelli et al. & 2012 & 2003-2011 & $\begin{array}{l}\text { Retrospective } \\
\text { cohort }\end{array}$ & 50 & 100 \\
\hline Pecorelli et al. & 2019 & $2015-2018$ & $\begin{array}{l}\text { Retrospective } \\
\text { cohort }\end{array}$ & 95 & 190 \\
\hline $\begin{array}{l}\text { PREOPANC } \\
\text { TRIAL }\end{array}$ & 2020 & 2013-2017 & $\begin{array}{l}\text { Randomised } \\
\text { control trial }\end{array}$ & 66 & 98 \\
\hline SHO et al. & 2012 & $2008-2011$ & $\begin{array}{l}\text { Retrospective } \\
\text { cohort }\end{array}$ & 61 & 71 \\
\hline $\begin{array}{l}\text { TAKAHASHI } \\
\text { et al. }\end{array}$ & 2011 & 2004-2007 & $\begin{array}{l}\text { Retrospective } \\
\text { cohort }\end{array}$ & 28 & 30 \\
\hline Tashiro et al. & 2018 & $2010-2017$ & $\begin{array}{l}\text { Retrospective } \\
\text { cohort }\end{array}$ & 67 & 94 \\
\hline $\begin{array}{l}\text { Timmermann } \\
\text { et al }\end{array}$ & 2019 & $2016-2018$ & $\begin{array}{l}\text { Retrospective } \\
\text { cohort }\end{array}$ & 33 & 99 \\
\hline Uchida et al. & 2020 & 2012-2019 & $\begin{array}{l}\text { Retrospective } \\
\text { cohort }\end{array}$ & 52 & 148 \\
\hline $\begin{array}{l}\text { Yoshitomi et } \\
\text { al. }\end{array}$ & 2018 & $2010-2016$ & $\begin{array}{l}\text { Retrospective } \\
\text { cohort }\end{array}$ & 31 & 7 \\
\hline Yoshiya et al. & 2019 & $\begin{array}{l}\text { Not } \\
\text { available }\end{array}$ & $\begin{array}{l}\text { Retrospective } \\
\text { cohort }\end{array}$ & 9 & 11 \\
\hline
\end{tabular}


Table 2: Summary of findings:

Neoadjuvant Treatment compared with Surgery first for Pancreatic cancer

Patient or population: Resectable/Borderline resectable with pancreatic Adenocarcinoma

Intervention: Neoadjuvant Treatment

Comparison: Surgery First.

GRADE Working Group of grades evidence

High quality: Further research is very unlikely to change our confidence in the estimate of effect.

Moderate quality: Further research is likely to have an important impact on our confidence in the estimate of effect and may change the estimate. Low quality: Further research is very likely to have an important impact on our confidence in the estimate of effect and is likely to change the estimate. Very low quality: We are very uncertain about the estimate.

\begin{tabular}{|l|l|l|l|l|l|l|}
\hline Outcome & Number of & Number & Relative & No of & Quality & P \\
s & event & of event & effect & Participa & of the & Value \\
& (N/TOTA & (N/TOT & $(95 \%$ CI) & nts & evidenc & \\
& L & AL) & Relative & & (studies) & e \\
\end{tabular}


medRxiv preprint doi: https://doi.org/10.1101/2020.12.14.20248164; this version posted December 16, 2020. The copyright holder for this preprint (which was not certified by peer review) is the author/funder, who has granted medRxiv a license to display the preprint in perpetuity.

It is made available under a CC-BY-NC-ND 4.0 International license .

\begin{tabular}{|c|c|c|c|c|c|c|}
\hline & $\begin{array}{l}\text { (Neoadjuv } \\
\text { ant) }\end{array}$ & $\begin{array}{l}\text { Surgery } \\
\text { First) }\end{array}$ & $\begin{array}{l}\text { Risk(RR)/ } \\
\text { Odds ratio } \\
\text { (OR)/Weig } \\
\text { hted Mean } \\
\text { Difference } \\
\text { (WMD) }\end{array}$ & & $\begin{array}{l}\text { (GRA } \\
\text { DE) }\end{array}$ & \\
\hline $\begin{array}{l}\text { POSTOPERATIVE } \\
\text { PANCREATIC } \\
\text { FISTULA }\end{array}$ & $339 / 3686$ & $\begin{array}{l}2342 / 13 \\
335\end{array}$ & $\begin{array}{ll}\text { RR } & 0.66 \\
(0.55 & \text { to } \\
0.81) & \end{array}$ & $\begin{array}{l}17021 \\
(26)\end{array}$ & $\begin{array}{l}\oplus \oplus \oplus \\
\oplus \\
\text { high }\end{array}$ & $\begin{array}{l}<0.00 \\
01\end{array}$ \\
\hline
\end{tabular}


medRxiv preprint doi: https://doi.org/10.1101/2020.12.14.20248164; this version posted December 16, 2020. The copyright holder for this preprint (which was not certified by peer review) is the author/funder, who has granted medRxiv a license to display the preprint in perpetuity.

It is made available under a CC-BY-NC-ND 4.0 International license .

\begin{tabular}{|c|c|c|c|c|c|c|}
\hline & & & & & te & \\
\hline $\begin{array}{l}\text { DISTAL } \\
\text { PANCREATECTOMY }\end{array}$ & $167 / 673$ & $\begin{array}{l}625 / 220 \\
7\end{array}$ & $\begin{array}{ll}\text { OR } & 1.06 \\
(0.63 & \text { to } \\
0.78) & \end{array}$ & $\begin{array}{l}2880 \\
(10)\end{array}$ & $\begin{array}{l}\oplus \oplus \oplus \\
\ominus \\
\text { modera } \\
\text { te }\end{array}$ & 0.82 \\
\hline SOFT PANCREAS & $150 / 535$ & $\begin{array}{l}576 / 191 \\
3\end{array}$ & $\begin{array}{l}\text { OR } \\
0.61(0.48- \\
0.77)\end{array}$ & 2448 & $\begin{array}{l}\oplus \oplus \ominus \\
\ominus \\
\text { low }\end{array}$ & $\begin{array}{l}<0.00 \\
01\end{array}$ \\
\hline BLOOD LOSS & & & $\begin{array}{l}\text { WMD } \\
125.69 \\
(69.52- \\
181.86\end{array}$ & 3795 & $\begin{array}{l}\oplus \oplus \oplus \\
\ominus \\
\text { modera } \\
\text { te }\end{array}$ & $\begin{array}{l}<0.00 \\
01\end{array}$ \\
\hline $\begin{array}{l}\text { PANCREATIC DUCT } \\
\text { DIAMETER }\end{array}$ & & & $\begin{array}{l}0.00 \quad(- \\
0.38,0.38)\end{array}$ & 284 & $\begin{array}{l}\oplus \ominus \ominus \\
\ominus \\
\text { very } \\
\text { low }\end{array}$ & 1.0 \\
\hline COMPLICATIONS & $445 / 1550$ & $1477 / 42$ & OR $\quad 0.90$ & 5846 & $\oplus \oplus \oplus$ & 0.39 \\
\hline
\end{tabular}


medRxiv preprint doi: https://doi.org/10.1101/2020.12.14.20248164; this version posted December 16, 2020. The copyright holder for this preprint (which was not certified by peer review) is the author/funder, who has granted medRxiv a license to display the preprint in perpetuity.

It is made available under a CC-BY-NC-ND 4.0 International license .

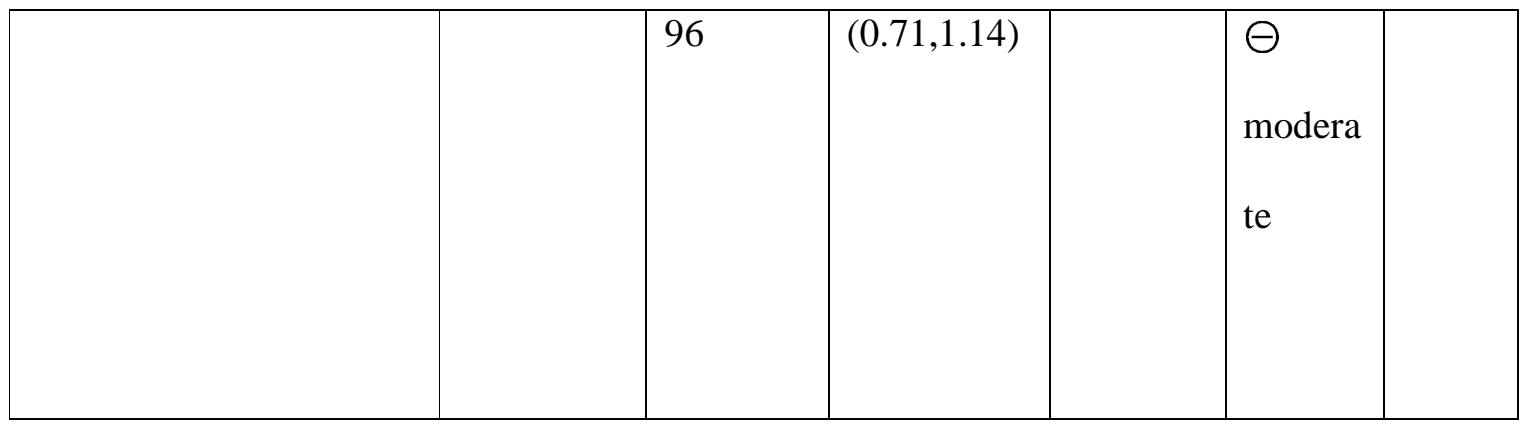

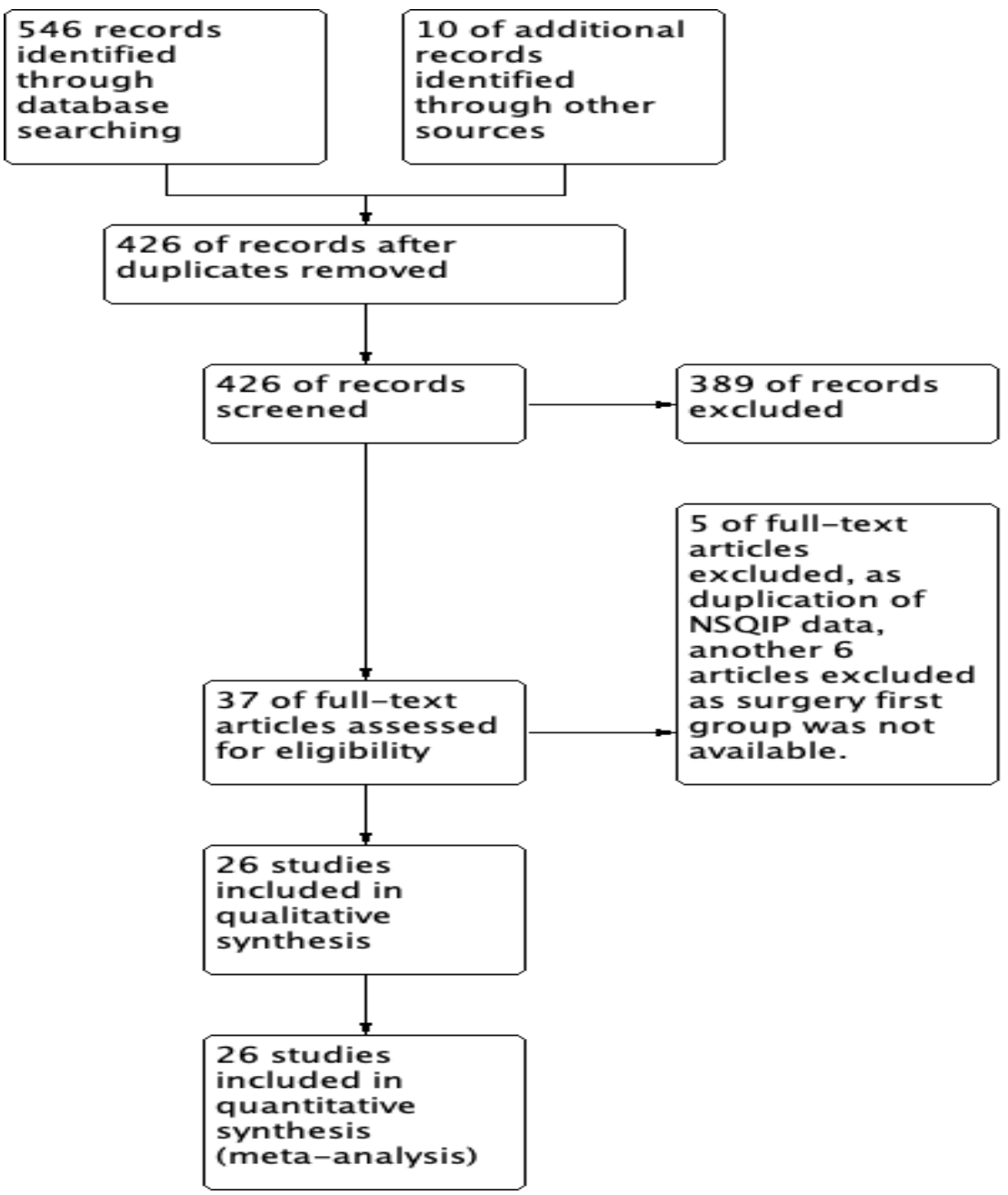

Figure 1: PRISMA flow chart. 
medRxiv preprint doi: https://doi.org/10.1101/2020.12.14.20248164; this version posted December 16, 2020. The copyright holder for this preprint (which was not certified by peer review) is the author/funder, who has granted medRxiv a license to display the preprint in perpetuity.

It is made available under a CC-BY-NC-ND 4.0 International license .

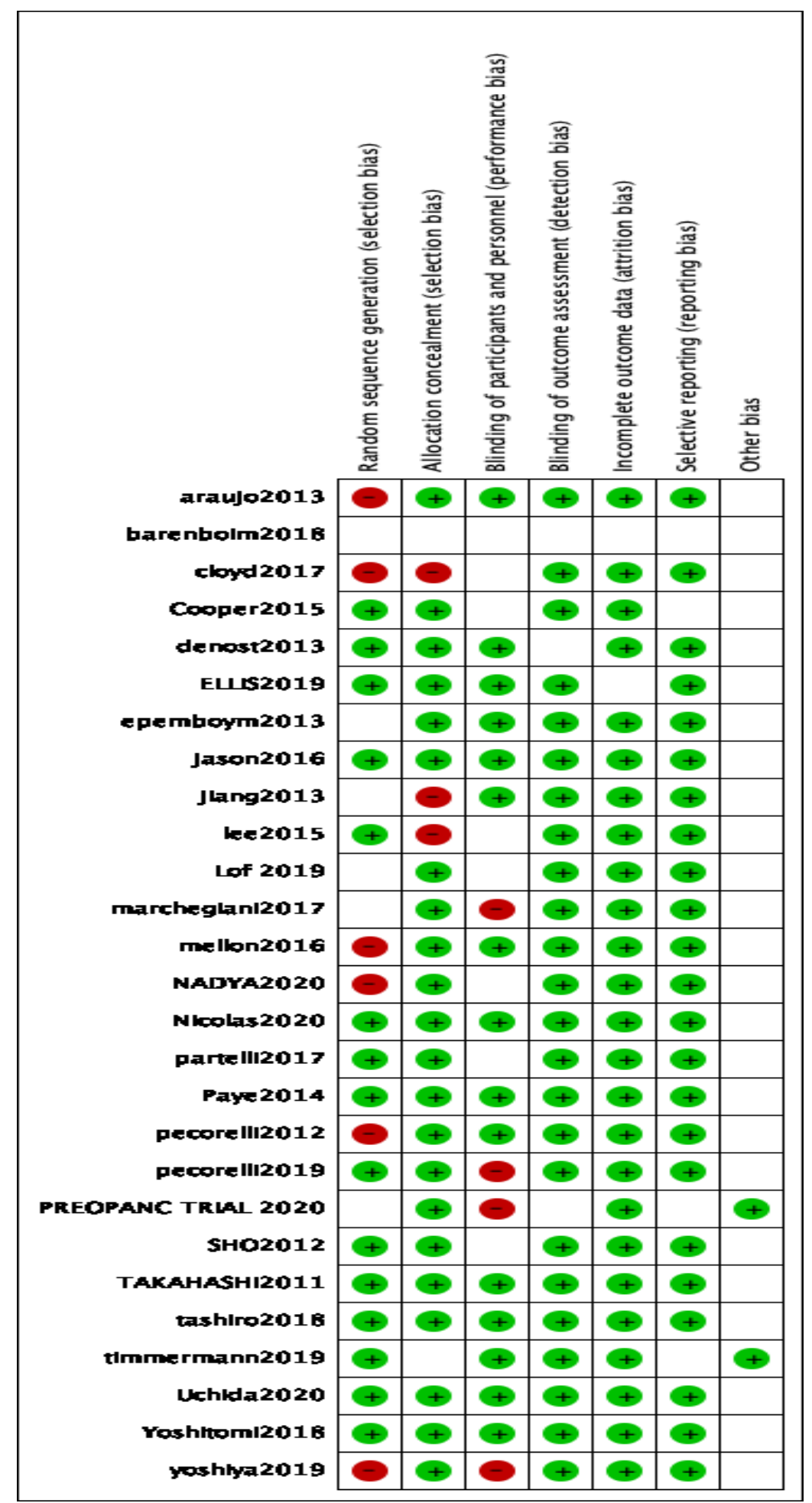


medRxiv preprint doi: https://doi.org/10.1101/2020.12.14.20248164; this version posted December 16, 2020. The copyright holder for this preprint (which was not certified by peer review) is the author/funder, who has granted medRxiv a license to display the preprint in perpetuity.

It is made available under a CC-BY-NC-ND 4.0 International license .

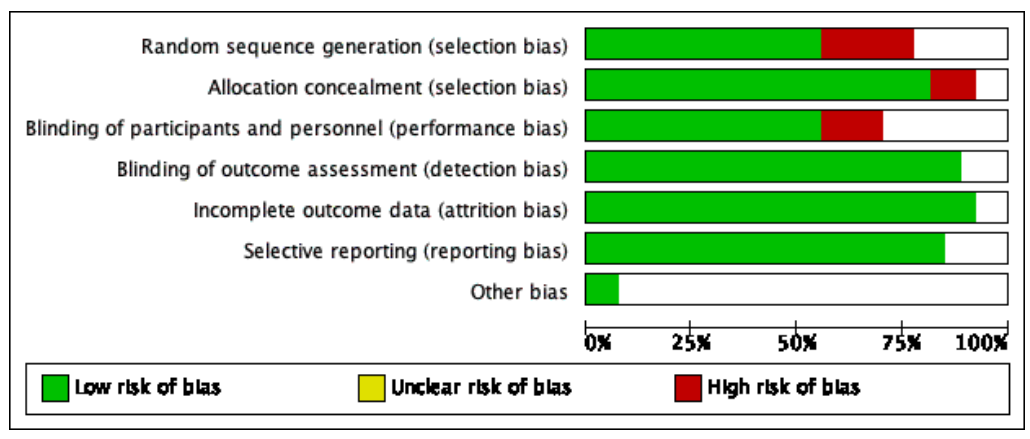

FIGURE 2 (a) Risk of bias summary: review authors' judgements about each risk of bias item for each included study (b) Risk of bias graph: review authors' judgements about each risk of bias item presented as percentages across all included studies.

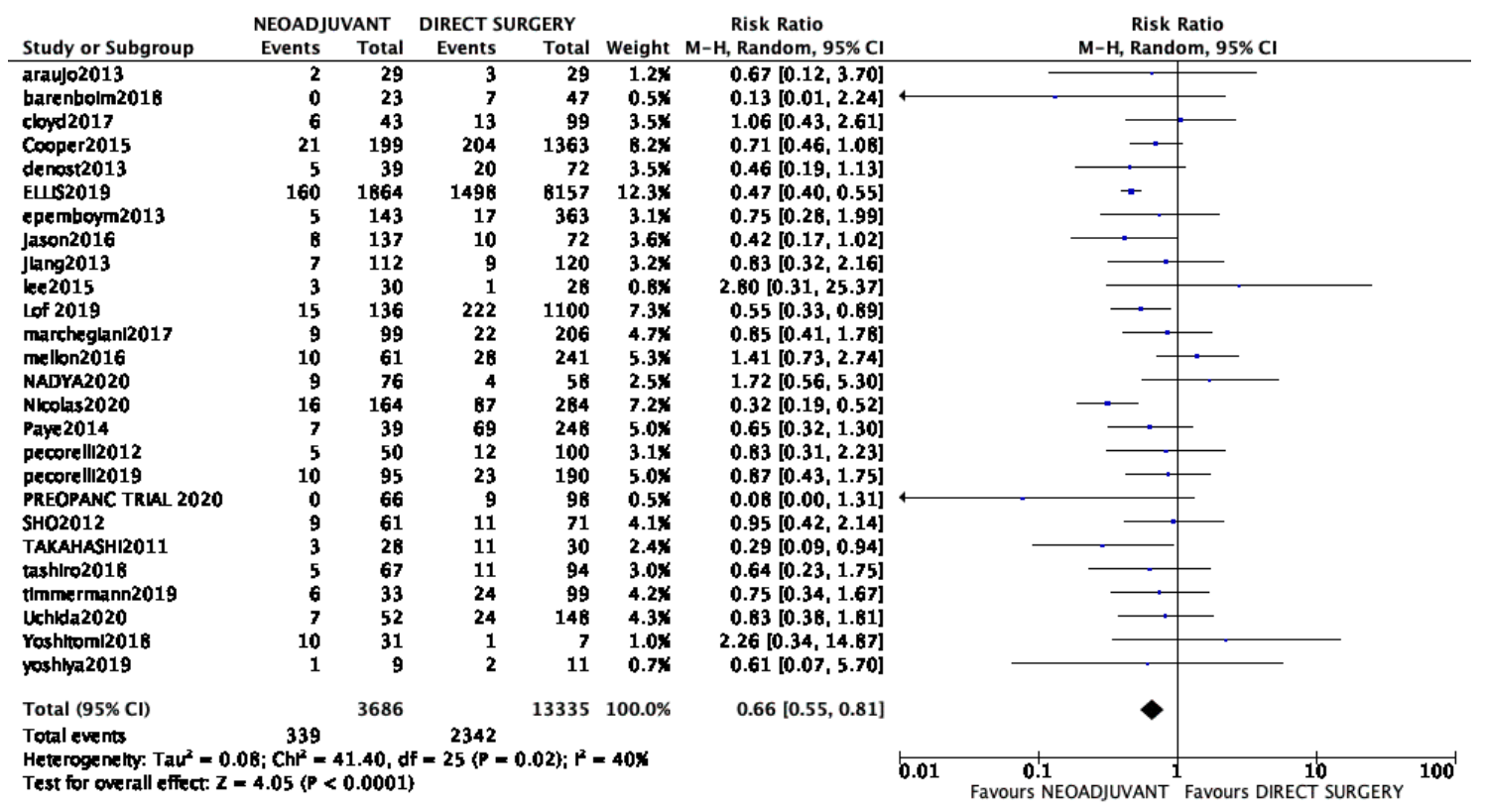

Figure 3. Forest plot of comparison: 1 Neoadjuvant chemoradiotherapy vs direct surgery in pancreatic cancer for postoperative pancreatic fistula. 
medRxiv preprint doi: https://doi.org/10.1101/2020.12.14.20248164; this version posted December 16, 2020. The copyright holder for this preprint (which was not certified by peer review) is the author/funder, who has granted medRxiv a license to display the preprint in perpetuity.

It is made available under a CC-BY-NC-ND 4.0 International license .

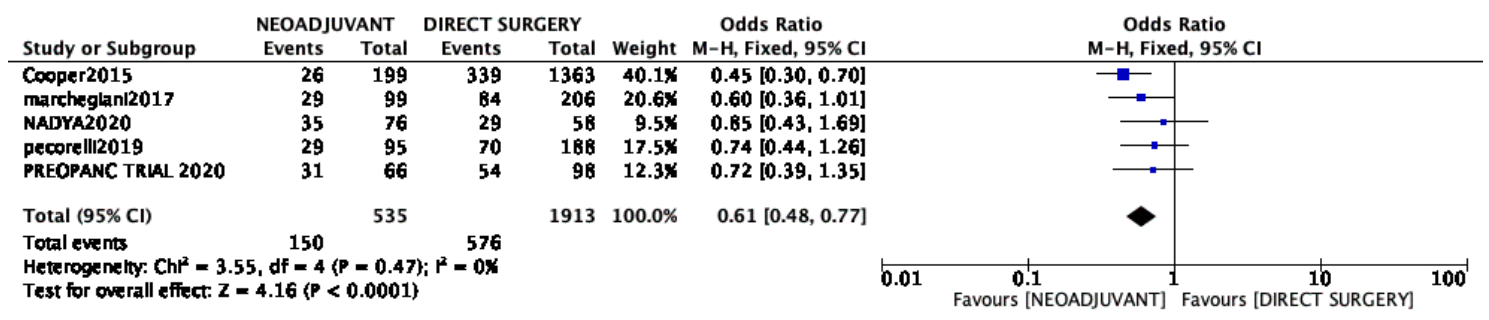

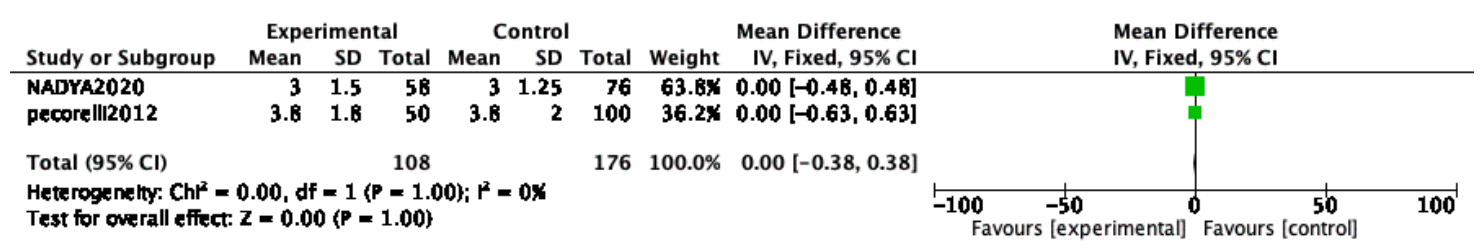

\begin{tabular}{|c|c|c|c|c|c|c|c|c|c|c|c|}
\hline \multirow[b]{2}{*}{ Study or Subgroup } & \multicolumn{3}{|c|}{ neoadjuvant } & \multicolumn{3}{|c|}{ surgery } & \multicolumn{2}{|r|}{ Mean Difference } & \multirow{2}{*}{\multicolumn{2}{|c|}{$\begin{array}{l}\text { Mean Difference } \\
\text { IV, Random, } 95 \% \mathrm{CI}\end{array}$}} & \\
\hline & Mean & SD & Total & Mean & SD & Total & Weight & IV, Random, $95 \% \mathrm{CI}$ & & & \\
\hline araujo2013 & 600 & 175 & 29 & 600 & 161.25 & 29 & B.1\% & $0.00[-86.61,86.61]$ & & - & \\
\hline epemboym 2013 & 1,500 & 500 & 143 & 1,000 & 250 & 363 & B.1\% & $500.00[414.11,585.89]$ & & & - \\
\hline Jason2016 & 600 & 137.5 & 137 & 400 & 101.5 & 72 & $9.6 \%$ & $200.00[167.14,232.86]$ & & - & \\
\hline Jlang2013 & 1,120 & 350 & 112 & 1,240 & 430 & 120 & $7.6 \mathrm{x}$ & $-120.00[-220.60,-19.40]$ & & & \\
\hline lee2015 & 1,269 & $1,079.8$ & 30 & $1,127.5$ & $B 96.5$ & 28 & $1.1 \mathrm{x}$ & $141.50[-367.98,650.98]$ & & & \\
\hline Lof 2019 & 325 & 81.25 & 136 & 283 & 100 & 1100 & $9.9 x$ & $42.00[27.12,56.88]$ & & $=$ & \\
\hline marcheglan12017 & 310 & 77.5 & 26 & 200 & 487.5 & 68 & $6.9 \%$ & $110.00[-9.64,229.64]$ & & & \\
\hline mellon2016 & 500 & 987.5 & 61 & 350 & 487.5 & 241 & $3.3 \%$ & $150.00[-105.34,405.34]$ & & & \\
\hline NADYA2020 & 637.5 & 554.2 & 76 & 430 & 380.2 & 76 & $5.8 \%$ & $207.50[56.40,358.60]$ & & - & \\
\hline pecorell12012 & $B 05$ & 575 & 50 & 604 & 482 & 100 & $4.8 \%$ & $201.00[15.73,386.27]$ & & & \\
\hline pecorell12019 & 350 & 75 & 95 & 300 & 51.25 & $1 B B$ & $9.9 \%$ & $50.00[33.23,66.77]$ & & $=$ & \\
\hline PREOPANC TRIAL 2020 & 900 & 225 & 66 & 900 & 200 & 98 & B.7\% & $0.00[-67.19,67.19]$ & & & \\
\hline SHO2012 & 1,530 & 628.5 & 61 & 1,216 & B30 & 71 & $\mathbf{3 . 4 \%}$ & $314.00[64.70,563.30]$ & & & \\
\hline tashiro 2018 & 997 & 167 & 67 & 802 & 111 & 94 & $9.3 \%$ & $195.00[149.15,240.85]$ & & $\infty$ & \\
\hline Yoshltom/201B & 1,274 & 961 & 31 & 1,347 & 1,111 & 7 & $0.4 \times$ & $-73.00[-962.84,816.84]$ & & & \\
\hline yoshlya2019 & 443 & 297 & 9 & 387 & 277 & 11 & 3.37 & $56.00[-197.86,309.86]$ & & 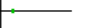 & \\
\hline Total $(95 \% \mathrm{Cl})$ & & & 1129 & & & 2666 & $100.0 \%$ & $125.69[69.52,181.86]$ & & & \\
\hline $\begin{array}{l}\text { Heterogenelty: Taur } \\
\text { Test for overall effect }\end{array}$ & 3.39 & $1^{2}=2$ & 4.10, d & & & & & & $\begin{array}{c}-500 \quad 0 \\
\text { Favours [surgery] }\end{array}$ & Favours [n & $\begin{array}{l}500 \quad 1000 \\
\text { eeoadjuvant] }\end{array}$ \\
\hline
\end{tabular}

Figure 4. Forest plot of comparison (a) SOFT PANCREAS (b) pancreatic duct diameter. (c)

Blood loss 
medRxiv preprint doi: https://doi.org/10.1101/2020.12.14.20248164; this version posted December 16, 2020. The copyright holder for this preprint (which was not certified by peer review) is the author/funder, who has granted medRxiv a license to display the preprint in perpetuity.

It is made available under a CC-BY-NC-ND 4.0 International license.

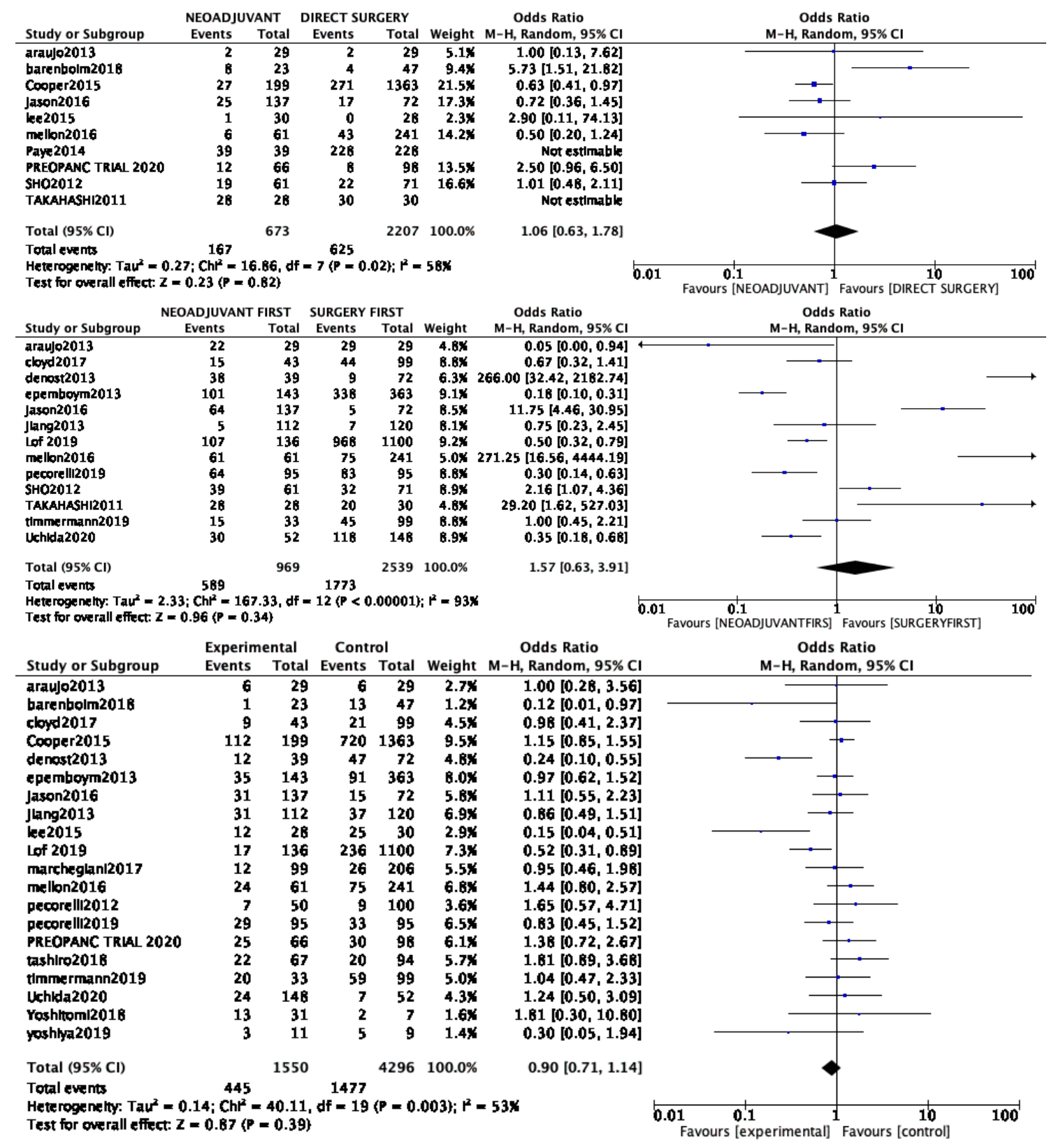

Figure 5. Forest plot of comparison (a) distal pancreatectomy (b) borderline resectable pancreatic tumours (c) overall complications. 